\title{
An essay on the history of citizenship in Latin America from a long-term perspective
}

\author{
LUCIANO ENRIQUE ANDRENACCI ${ }^{12}$ \\ 1 Universidad nacional de San Martín (UnSAM), Buenos Aires, Argentina \\ 2 Facultad latinoamericana de Ciencias Sociales (Flacso), Buenos Aires, Argentina
}

\begin{abstract}
This essay presents a view on the history of citizenship in Latin America. The classical literature defines citizenship as a series of tensions between representations of universality and equality, derived from how prerogatives and obligations of the individual members of territorial political organizations developed through history. In addition, the literature considers citizenship as a material and symbolic status whose relative universality and equality depend on concrete historical situations. The study proposes a long-term view identifying moments in history where these tensions appear, showing periods of equilibrium and critical junctures, which allows the perception of interesting aspects of the history of political and social inclusion in Latin American countries. The period between the first decades of the twentieth century and the present day) witnessed dramatic and non-linear processes. This moment can be seen as a series of regional movements toward an equilibrium that guarantees deeper inclusion of citizens in most political and social aspects, due to broader political regimes and as states more capable of delivering effective public policies.
\end{abstract}

Keywords: Citizenship. Latin America. History. Long term.

\section{Um ensaio sobre a história da cidadania na América Latina a partir de uma perspectiva de longo prazo}

\section{Resumo}

Este ensaio apresenta um ponto de vista sobre a história da cidadania na América Latina. Como na literatura relacionada clássica, a cidadania é definida como uma série de representações das tensões entre universalidade e igualdade-derivadas da forma em que as prerrogativas e obrigações dos membros individuais das organizações políticas territoriais desenvolveram através da história- e um status material / simbólico cuja universalidade e igualdades relativas dependem de situações históricas concretas. Propomos uma visão de longo prazo e uma periodização dessas tensões, mostrando pontos de equilíbrio e momentos críticos, o que nos permite perceber alguns aspectos interessantes da história de inclusão política e social nos estados territoriais da América Latina. Argumenta-se que o último século (entre as primeiras décadas do século 20 e do presente), apesar da natureza dramática e não-linear de muitos de seus processos, pode ser visto como uma série de movimentos regionais de amplitude em direção a pontos de equilíbrio que garantem uma inclusão cidadã mais ampla e profunda, na maioria dos aspectos políticos e sociais, graças a regimes políticos mais amplos, bem como a estados mais capazes de gerar efeitos materiais substanciais em seus territórios.

Palavras chave: Cidadania. América Latina. História. Longo prazo.

\section{Un ensayo sobre la historia de la ciudadanía en América Latina desde una perspectiva a largo plazo}

\section{Resumen}

Este ensayo presenta un punto de vista sobre la historia de la ciudadanía en América Latina. A partir de la literatura clásica, se toma a la ciudadanía como una serie de representaciones de las tensiones entre universalidad e igualdad, derivadas del modo en que se desarrollaron a través de la historia las prerrogativas y obligaciones de los individuos miembros de las organizaciones políticas territoriales; y un estatus material y simbólico cuya universalidad e igualdad relativas dependen de situaciones históricas concretas. Se propone una visión a largo plazo de estas tensiones, y una periodización de la observación, que muestra cuáles son los puntos de equilibrios que se producen entre coyunturas críticas, y que permite percibir algunos aspectos interesantes de la historia de la inclusión política y social en los Estados territoriales de la región. Se argumenta que el último siglo (entre las primeras décadas del siglo XX y el presente), a pesar de la naturaleza dramática y no lineal de muchos de sus procesos, puede ser visto como una serie de movimientos de amplitud regional hacia puntos de equilibrio garantizan una mayor inclusión ciudadana en la mayoría de los aspectos políticos y sociales, gracias a regímenes políticos más amplios y Estados más capaces de generar efectos materiales sustanciales en sus territorios.

Palabras-clave: Ciudadanía. América Latina. Historia. Largo plazo. 


\section{INTRODUCTION}

In this paper I propose to understand citizenship, in contemporary territorial states, as a set of tensions that occur between the equality and universality contained in the formal status, as well as in its normative assumptions, and actual material and symbolic inequality. These tensions are inherent to any state. But, in some regions, for historical reasons, they seem to be more intense. The objective of this essay is to propose a long-term perspective on the history of these citizenship tensions in Latin America: a place where inequalities are old, intense and resilient, although institutional arrangements have sedimented, for more than two centuries, in republican forms carrying egalitarian normative assumptions.

A regional and long-term perspective necessarily means to overlook many singularities and specificities. Yet, I believe it is possible to generalize that Latin American citizenship presents tensions of such intensity, that orienting them through the mechanisms of classical capitalist polyarchies has been a highly problematic, albeit not an altogether unfeasible process. To throw some light into this, I firstly put forward some conceptual definitions of citizenship, aimed at understanding it as a set of tensions inherent to modern territorial states. I then move to propose a way of reading and periodizing these tensions in the long term, trying to capture the phases common to all 20 countries. And I close with a couple of ideas on the present, which the long-term perspective allows me to derive.

\section{LA CIUDADANÍA EN PERSPECTIVA HISTÓRICA}

I use citizenship, as multiple authors do (WALZER, 1983; DONZELOT, 1984; ANDREWS, 1991; RIESENBERG, 1992; ROCHE, 1992; ROSANVALLON, 1992, 2015; TURNER, 1993; ZOLO, 1994; BEINER, 1995; THOM, 1995; TILLY, 1995; BENDIX, 1996; BIRNBAUM, 1996; GIDDENS, 1996; HEATER, 1999; MAGNETTE, 1996; BOTTOMORE and MARSHALL, 1998; ANDRENACCI, 2003; TILLY, 2005; SOMERS, 2008; SKINNER, 2010; LEYDET, 2017), to address, in historical perspective, the problems of membership, participation, difference and equality in contemporary societies organized as territorial or nation-states.

Perhaps forcing a bit some of the common aspects in the related academic literature, citizenship is presented here as a series of representations (ideas and images, more or less organized in narratives) about universality and equality, derived from the way in which prerogatives and obligations developed into modern rights and duties, were codified by positive laws, and condensed in forms of membership of individuals to European-like political organizations (today territorial states).

At the same time, however, citizenship constitutes a material status (a position in social stratification, partly acquired and partly ascribed) whose relative universality or equality depend on concrete historical situations. Two central variables define (and are defined by) the representations, producing the "materiality" of citizenship: political regimes and state capacities.

Political regimes in contemporary territorial states function, in practice, as polyarchies (DAHL, 1971; O'DONNELL, 1998, 2010). Although the concept was devised to discuss the nature of representative democracies of the 20th century, it is not difficult to extend it to any political regime where power is not centralized and concentrated. A set of rules frames the interaction of a number of powers competing and cooperating to govern. The result of these relationships determines a large part of what a state does or does not do, directly impacting (though not linearly) on the materiality of citizenship.

Polyarchies "filter" the representations of citizens and key actors, but the concrete aspects of citizenship depend on the actual levels of state capacity (as in MANN, 1997, 2012; WEAVER and ROCKMAN, 1993; or EVANS, 1995). States are organizations that deploy infrastructural power (MANN, 1995) over a territory. They can be relatively autonomous from external powers and adequately embedded in internal powers (EVANS, 1995); they can generate broad concrete material effects; and they can obtain sufficient legitimacy from this effectiveness and that autonomy / embeddedment. Or state powers may be determined by extraterritorial or parastatal factors; it may be occupied by predatory elites; concentrated in or limited to portions of the territory, or generating effects for too restricted social strata; and it could thus produce low or no legitimacy at all.

Certainly, the use of the term citizenship relates to politico-territorial organizations more inclusive than others, as well as to types of membership with prerogatives less unequally distributed than others. But history shows more dynamic tensions than lasting points of arrival. The genealogy of the term moves us to the way in which these problems of membership and equality were discussed by a group of cities in the basin of the Mediterranean Sea some 2,700 years ago; and how these categories 
were reappropriated in the political conflicts that gave birth to the European republican states between the seventeenth and nineteenth centuries (HEATER, 1999). But it was the practices that appeared in recent history, and the way they understood and resignified those pasts, which defined citizenship in the way we use it today.

Space issues prevent us from elaborating further on this. Let us consider only that the territorial states of Europe and North America followed peculiar paths, in the way in which the constitutive tensions of contemporary citizenship were deployed. Political regimes and state functions were key in this, establishing acceptable and non-acceptable conflicts, floors of material well-being and modes of collective regulation. In the stabilization cycle that ran from the Second World War to the present, political systems managed to channel key political and social conflicts, "offering citizenship". Civil rights expanded, encompassing classic individual liberties and guarantees, and merging them into universalist notions such as "human rights". The patterns of political participation were broadened, granting electoral rights to the majority of citizens and multiplying the options for political participation. And state intervention in socio-economic processes multiplied, creating a guarantee -of sorts- to minimum material conditions of life capable of limiting or reducing the effects of class conflicts: the "Welfare State".

But, since citizenship is a tension, common floors and conflict channelling can lose legitimacy or cease to be justified when social or political inequality settles, hardens, or coagulates asymmetrically. Contemporary citizenship not only shows enormous cyclical difficulties to resolve these tensions, but also presents limits to process difference (YOUNG, 1996). "The normal" conceals arrangements of power that occur between private interests and are generalized as public, presenting themselves as the interests of the majority and galvanizing persistent inequalities (TILLY, 1999). One of the most significant and durable of these is gender inequality, other equally persistent but more variable inequalities are usually categorized as socioeconomic or ethnocultural.

Here, a long-term perspective (BRAUDEL, 1987, recently rediscovered by ARMITAGE and GULDI, 2015, among others) is applied to these issues in the Latin American region, one hopefully helpful to capture its dynamics. Between "critical junctures" (COLLIER and COLLIER, 2002) that are substantially similar for the entire region, one can identify periods of relative equilibrium and institutional inertia, also substantially similar in most or all Latin American territorial states. In the following table, I present a comparative synthesis of these phases, to then dedicate the rest of the paper to a set of interpretative hypotheses about them. Although the sequence and the timelines may seem too general or imprecise, as a consequence of a history that only converges gradually and partially, the objective is to grasp the big picture.

\section{Box 1}

\section{A comparative periodization of citizenship in Europe / North America and Latin America}

\begin{tabular}{|c|c|c|c|}
\hline $\begin{array}{c}\text { Europe / North } \\
\text { America }\end{array}$ & Periodization & Latin America & Periodization \\
\hline \multicolumn{4}{|c|}{ Ancient Citizenships } \\
\hline $\begin{array}{l}\text { Mediterranean and } \\
\text { Roman Citizenships }\end{array}$ & $\begin{array}{l}\text { From the appearance of Classical Ancient } \\
\text { Cities (circa X Century BC) until the } \\
\text { dissolution of the Western Roman Empire } \\
\text { (circa VI Century AD). }\end{array}$ & Precolonial Citizenships. & $\begin{array}{l}\text { From the appearance of territorial } \\
\text { states (circa V-VI Centuries AC) until the } \\
\text { formation of Mesoamerican and Andean } \\
\text { states (circa XII-XIII Centuries AD). }\end{array}$ \\
\hline \multicolumn{4}{|c|}{ Pre-modern Citizenships } \\
\hline $\begin{array}{l}\text { Medieval } \\
\text { Citizenships }\end{array}$ & $\begin{array}{l}\text { From the formation of medieval Europe } \\
\text { (circa VII Century) to the formation of } \\
\text { centralized monarchies (circa XV century). }\end{array}$ & $\begin{array}{l}\text { Early and Mid-colonial } \\
\text { Citizenships. }\end{array}$ & $\begin{array}{l}\text { From the European invasions (circa XV } \\
\text { Century) to the consolidation of colonial } \\
\text { regimes (circa XVI-XVII Centuries). }\end{array}$ \\
\hline \multicolumn{4}{|c|}{ Modern or Contemporary Citizenships } \\
\hline $\begin{array}{l}\text { Monarchical } \\
\text { Citizenships }\end{array}$ & $\begin{array}{l}\text { From the consolidation of centralized } \\
\text { monarchies. }\end{array}$ & $\begin{array}{l}\text { Ciudadanías coloniales } \\
\text { tardías y ciudadanías } \\
\text { excluyentes. }\end{array}$ & $\begin{array}{l}\text { Desde la centralización de los Imperios } \\
\text { Coloniales (siglo XVII) hasta su colapso } \\
\text { (siglo XIX). }\end{array}$ \\
\hline $\begin{array}{l}\text { Polyarchical } \\
\text { Citizenships }\end{array}$ & $\begin{array}{l}\text { Generalización de Estados territoriales con } \\
\text { regímenes políticos poliárquicos (desde } \\
\text { fines del siglo XIX hasta el presente). }\end{array}$ & $\begin{array}{l}\text { Inclusive and Inclusionist } \\
\text { Republican Citizenships. }\end{array}$ & $\begin{array}{l}\text { From the implosion of exclusive republics } \\
\text { (XIX-XX Century) to the present. }\end{array}$ \\
\hline
\end{tabular}

Source: Elaborated by the author. 


\section{LATIN AMERICAN CITIZENSHIP IN HISTORICAL PERSPECTIVE}

Since Iberian Peninsula Europeans built state organizations in American territory, imposing their particular institutions those on New World societies, the tensions of citizenship tended to be particularly dramatic. Political regimes notably reluctant to expand direct or indirect inclusion were combined perversely with predatory state organizations, or with strong limitations of material capacity, leading to markedly unequal models. From a comparative and long-term perspective, these processes had common aspects for the entire region, as well as some important differentiation patterns.

Regarding the common aspects. Certainly, Latin American citizenships maintained important degrees of similarity with the way in which Southern and Western European citizenship was deployed, because Latin American territorial states were by-products of European institutions. Since these institutions were superposed on (rather than merged to) the few stable political-territorial units pre-existing in the continent (in Mesoamerica and the Andean World), the "creation" kept a degree of family resemblance. Furthermore, from the XVI to the XVIII century, a relationship of active exchange, mimesis and emulation took place between the motherlands and the colonies, as well as with competing empires and neighbouring colonies. Last but not least, on their common baggage and institutional inertias, they went through quite similar critical junctures, within the growingly integrated political and commercial world of the times.

From there on, colonial and independent history produced conflicts of a new kind, as well as novel processes of adaptation and institutional creation. At least three issues, which fed the tensions of citizenship throughout Latin America, provided principles of singularization that would contribute to differentiate national experiences: the problematic character of development within the emerging capitalist global economy; the relative weakness of states as territorial units, political systems and bureaucratic organizations; and the high asymmetry, fragmentation and segmentation of social structures. The ways in which these tensions were deployed in each experience gave rise to important differences, within a remarkable degree of similarity, given the size of the region. In this work I am interested in highlighting the common aspects.

\section{Precolonial citizenships?}

Strictly speaking, of course it is not possible to find precolonial citizenship in Latin America. But there is an interesting question that this perspective allows to pose. Were there political-territorial organizations with tensions comparable to those of European citizenship before the invasions? It is highly probable, although the available knowledge only allows us to make general hypotheses. Establishing forms of belonging and inequality in pre-European America is a company for which there are important information deficits (BETHELL, 1990; ROJAS RABIELA and MURRA, 1999), although technological change in archeology and paleontology is providing new tools.

What do we know? According to specialists, the high geographical dispersion, the low demographic pressure, and the great relative availability of natural resources, may have influenced the late appearance and smaller number of stable territorial political organizations in the Americas. From the available evidence we know that, perhaps since pre-Christian centuries, organizations with territorial political capacity were projected from the south and north of Mesoamerica (in present-day Mexico); as well as from the coasts, valleys and plateaus of the Central Andes (in present-day Peru). At least since the beginning of the XIV century, one of these peoples, the Mexicas or Aztecs, imposed their political domination from the region where Mexico City is located today towards the north and south. Slightly later, in South America, groups sharing the Cusco valley language (quishwa), which the Spanish called Quechuas or Incas, controlled a large portion of Western South American plateaus and valleys at least from the XV century, from present-day Ecuador all the way to Chile and Argentina.

In a way not too different from that of state organizations in the Old World, the Aztecs and Incas had forms of social division of collective labour that had crystallized into stable social hierarchies, comparable to European and Asian castes. An extended clan stood out, forming a kind of political and religious nobility with military and logistical imposition capacity, while subaltern clans dominated by force or co-optation provided economic and military tributes sacralized by religion.

Upon the arrival of the Spanish, the Mexica and Inca worlds impressed their invaders as feudal European empires, with intricate networks of dependency / vassalage which cusps were occupied by the lords of Tenochtitlan and Cusco. If domination in Mexico was more like an actual feudal network, in the Tawantinsuyu (a Quechua expression that may have been used as 
the name of the realm) a military and logistics centralized bureaucracy managed most of the territory, as in more centralized Asian organizations. In Mexico there were surpluses that were exchanged in practices similar to European and Asian trade, although there is no evidence that the forms of non-collective property that this implied extended to the land. In the Andes the structure of economic activity seems to have been strictly collectivist, and the patterns of exaction seem to have been more intense.

Although the Mexica and Quechua states failed to stop the invaders, their institutional frameworks were the bases on which the colonial empire was constituted (PEASE and MOYA PONS, 2000). Quite better known is how the Spanish superimposed their political and religious hierarchy on the pre-existing social networks. Using the asymmetries of social power to appropriate the material surpluses appropriated by the two pre-European states, they successfully redirected the exploitation to the economic enterprises that could make the colonial world profitable in European terms of trade and wealth. With enormous efficiency also -considering the vastness of the territory and the short time elapsed- they achieved diffuse social control of the population thanks to effective combinations of violence and acculturation.

In the territories where political organizations capable of infrastructural power of the European type (the vast majority of American spaces) had not been developed, the inexistence of traditions of social subordination and systematic economic exploitation hindered and made the colonial process less efficient, demanding even greater intensities of violence and acculturation. Alternatively, the Europeans proceeded to relocate populations (imitating the Incas) and to import African population with forms of slaveholding, on unprecedented scales. The colonial empires were built with centres of infrastructural power in the spaces (in historical order Santo Domingo, Mexico, Peru and Brazil) of greater demographic and economic density, old and new.

\section{Colonial Citizenships}

The constitutive tensions of modern Latin American citizenship, like the very idea of citizenship, came to the Americas in European ships. They were an essentially European way of processing the issues of membership and inequality; and they were reflected in peculiar syntheses between the political-organizational moments that the European imperial centres were going through, as well as the ways in which colonial structures processed the incorporation of the new territories and populations.

The Castilian-Aragonese and Portuguese monarchies were in transition from feudalism -mosaics of diffuse, half imposed and half contractual powers- and the progressively centralized and intense power networks of the modern state. Personal and communal ties of territorialized and sacralized vassalage materialized as tributes, taxes, personal services and levies, in forms of asymmetric reciprocity. They could be highly beneficial and desirable, like those that bonded a prince with his kin; or highly unequal and undesirable, such as rural serfdom. Transposed to America, the structure kept similarity with Europe, but acquired new, pronounced and resilient forms of inequality. While for some Europeans the colonial process seemed to have opened opportunities of social promotion or upgrades of social ties, historiography provides numerous reasons to suppose that for most native Americans and forced African migrants the new world was markedly worse than that of their respective pasts.

The colonial process deployed this in stages that, although differentiable, did not substantially alter the whole. At an early stage, from the late XV century until the XVI century, the model of conquest was a matter of ventures led by a few noble and a large number of private entrepreneurs, in the way the Portuguese had tested in Africa and Asia. The initiatives led to the establishment of an archipelago of autonomous commercial establishments, protected by temporary military posts (more independent and flexible in the case of the Portuguese than in that of the Spanish). Through a system of concessions, the "entrepreneurs" ran with the risks of the initiative and were transformed into territorial lords of the new spaces. In exchange for the power to receive the tribute due to the king, the new lords appropriated the surplus and could demand labour, usually forced. The concessions repeated, expectedly, the models of the medieval pacts and fueros, turning the American businessman into a sort of feudal lord, and the locals, "distributed" (repartidos) or "entrusted" (encomendados) to him, into his serfs.

As the American establishments expanded and began to show benefits, the Empires reorganized to maximize them, deploying delegating bureaucracies. The commercial stations acquired progressive state character, becoming a network of cities, of variable size according to the dimensions of their commercial economies and their hinterlands. In this mesocolonial stage, 
takes place the actual constitution of political-territorial organizations that will distribute among themselves most of the American territory.

In the upper social stratum an aristocracy of European origin developed the most profitable economic activities (agriculture, mining and trade) and directly or indirectly controlled the administrative political positions (the military tasks, the ecclesiastical ones, and those regulating trade and justice). This elite, relatively small and inbred, was extended (reluctantly) with the arrival of new European holders of mandates and royal grants (mercedes).

The elite shared the city with an American "creole" sub-elite (often mestizos and mulattoes legally recognized by their "white" fathers) who functioned as a medium-high stratum dependent on favours from the upper elite. This sub-elite tended to expand with the arrival of other European immigrants without lineage, resources, or specific trades. It grew in size, asymmetrically associating with the European elite, and strategically claiming less social differentiation (relative to Europeans) and more social differentiation (relative to non "white" Americans). Eventually, subsequent generations of these sub-elites will determine the models of citizenship of independent Iberian-American states.

In the lower strata of the social structure, another radically new universe tended to be created. Unlike what happened in other parts of the globe, the annexation produced a very rapid and almost complete cultural and demographic destruction of the previous world (AMORIM and BOLEDA, 2009). The survivors were trapped in communities that paid tribute in kind, labour and personal services (including sexual). When the indigenous communities reached limits in their possibilities of reproduction and economic functionalization, the importation of African slaves added a new layer of singularity.

From the point of view of citizenship, this element was key to later American history. Although no one, in theory, could escape the networks of personal dependence or slavery, as colonies made their economic structures more complex and regained demographic momentum, a growing number of mestizos (children of Whites and Indians) and mulattos (children of Whites and Africans) escaped from these networks to play subordinate economic roles of greater autonomy in the cities, progressively resembling urban salaried workers. This "lower middle stratum" strategically collaborated with the Creole sub-elite, as an economic and military workforce, in the creation of the new states.

Another key element will have future institutional effects. In America, the social division of labour, unlike the Old World, admitted a certain flexibility. A sort of parallel world with its rules, governed essentially by monetary capacity, through influence peddling and perks, subtly eroded and gradually transformed hierarchies. This informal regulation of citizenship converted key socially relevant positions into "staples" susceptible of purchase, sale, and even inheritance; from the blood, to the distribution of land and Indians; from the positions in the public administration (and the economic benefits that they produced), to authorizations to legal (and illegal) trade. The "caste" society (the popular use of the word casta was significant), was becoming flexible, like its European parallels, by the "corrosion" of coin, even if it was based on substantive, intense and resilient inequalities.

It is well known that in Europe, diffuse ideas of justice and equality combined with social change to undermine the legitimacy of monarchies, contributing to precipitate the political and social transformations from which the republics and modern parliamentary monarchies arise. In Latin America, the fall of the Colonial Empires opens the possibility of questioning the political and social arrangements of caste society -although for many, more reluctantly than official histories colourfully pretend. But it will take several decades until the emergence of a substrate of egalitarian representations permits to raise put these questions in terms of citizenship.

\section{Modern or Contemporary Citizenships}

The present citizenships, in Latin America, arose from the political processes of autonomy and / or independence that gave rise to the current states and / or their predecessors. They developed in two distinct phases. In both, the inclusive and equalizing effects of republican systems contrasted with the resilience of ancient inequalities, and the shortage of open routes for a less asymmetrical social integration. But, while in the first phase the contrast was nothing short of extreme; in the second, there actually was an effective (if not linear) inclusion process, as well as a questioning (not necessarily successful) of the most important patterns of inequality.

The first phase begins with the processes of autonomies and independences, which last (at least) the first three decades of the XIX century. It continues with the slow consolidation of republican Latin American states during the rest of the XIX century. 
Because of the way in which political regimes and state capacity combined, I propose to qualify these stages of modern citizenships as "exclusive" (excluyentes). Mostly because the European administrations are replaced by nominally republican orders that alter only partially the asymmetry of social and political domination. Only during the second half of the nineteenth century, the change accelerates, when the link between the region and the global economy presses state organizations to develop a greater level of infrastructural power.

A second phase started, with few exceptions (perhaps that of Uruguay), only after the first decades of the 20th century, when Latin American states were forced to face, at the same time, the consequences of global reorganization produced by interimperial wars and crises in "core countries", and the tensions brought about by the growing intensity of political and social demands. I propose to qualify these stages as "inclusive" (incluyentes), because it is not difficult to find openings in political participation; as well as increases in state capacity that led to improvements, or less subordinated insertion of majorities, in the opportunities for material, urban and rural economic progress. Mixed with both appeared or reappeared issues of ethnic asymmetry, that can be understood as claims to redefine the symbolic borders of citizenship.

\section{Exclusive Citizenships}

In the late colonial period, the Spanish and Portuguese Empires entered a catastrophic spiral. Both crowns had embarked (with different intensities) on increasing metropolitan control of American territories and populations, which produced strong rearrangements and growing tensions with local elites and sub-elites. But processes of global impact, such as British growing hegemony and American independence, offered new alternative political and commercial mechanisms, intertwining in complex ways with conflict among American elites and between social strata for the redefinition of social power. Finally, the wars unleashed by the French Revolution put the two imperial centres in a crisis of survival.

The new states developed their institutional constructions within a universe of finite options (GUERRA, 2001; ANNINO and GUERRA, 2003; CHIARAMONTE, 2004). The dominant American elites, with more or less information and perspective, were not willing to make caste relations much more flexible (the minimum necessary to provide legitimacy); and they were prone to continue their predatory capture of state devices. Diffuse or explicitly, they sought "power above" and "order below" (LYNCH, 2008; MURILO DE CARVALHO, 1995). With few exceptions (Chile), political arrangements were highly unstable in both legitimacy and effectiveness.

The models of citizenship that derived from these new arrangements reflected these patterns and tensions (SÁBATO, 1999). Politics, in the first place, was strongly restricted to local notables, even in the regions where the independence coalitions had been broader (Gran Colombia and Río de la Plata). Along with the expected political exclusion of European whites, the new states presented themselves as the institutional heirs of indigenous tribute, while treating the emancipation of slaves with caution and ambiguity. Although the social structure suffered the rearrangements inherent to a long dramatic war (with the exception of Brazil, Central America and the Caribbean), there were no radical transformations. The new institutionality made the castes disappear in the law, while in practice it created politically oligarchic and socially segmented republics, according to cleavages of relative continuity with the past.

After the independences, behind the countless rebellions and small wars between regions, cities, and "parties" (small groups of notables with their clientele), for the appropriation of the few opportunities left by the fleeting state devices and the limited postcolonial economies, the new citizenships had an extremely partial and restrictive character, setting or resetting the bases of the "resilient exclusion" characteristic of Latin American territorial states (ANSALDI and GIORDANO, 2012a).

The most important transformative impulse will come only in the second half of the 19th century, when the new political-territorial units enter (voluntarily or not) the phase of global economic change at the origins of the present "Iong conjuncture" (ARRIGHI, 1999). For the region, the expansive phase of global trade generated growing markets for old and new raw materials, as well as attractive destinations for capital in search of opportunities for multiplication. Old centres were reinserted in new profitable circuits, while many marginal areas acquired centrality. Precarious state bureaucracies had access to progressively global credit, and multiplied their functions. The new influx produced novel social transformations again, such as the wave of immigrants from Europe, the Middle East and East Asia, which reconfigured the urban and rural wage-earning sectors. The new value of lands, finally, produced geopolitical clashes that ended up consolidating the borders of contemporary Latin American states.

The phase witnessed the recycling of old asymmetries and the production of new ones. The fate of the Latin American elites depended on new centres of power, in a "neocolonial" order in which the greater relative political independence was 
combined with new forms of financial and commercial heteronomy. Meanwhile, the change dealt final blows to a good part of the social dynamics of post-independence. In a few decades the postcolonial world gave way to a world more similar to the present than to the past. But if change softened old cleavages and generated new ones, it did not dramatically alter a social and political matrix of extreme inequality. States, in spite of their new capable bureaucracies, remained under the control, and the permanent dispute, of small elites with predatory habits. Behind the frequent conflicts between "liberal" and "conservative" cliques, Latin American polyarchies remained lukewarm republican, with tenuous and selective application of principles of freedom or equality. Latin American historiography characterized them as oligarchical regimes (ANSALDI and GIORDANO, 2012a).

This exclusive modernization, however, was both the point of arrival of postcolonial transformations and the point of departure for the tensions of modern citizenship. It is not difficult to see this in the new popular sectors demands of participation; in the peasant movements resistance to proletarianization; in the subaltern elites' claims to political power; or in the fractions of the elites that demanded cultural changes. The "solutions" to these tensions of citizenship tended to resemble notably throughout the region. The new states produced models of political participation broader than those of the Old Regime, although not less selective and exclusive. The socio-economic fluidity, on the other hand, was undoubtedly greater than that of the caste society; even if it generated, with few exceptions, very limited opportunities for upward social mobility.

The "exclusive" model certainly admitted important variations in intensity, which depended on the types of socioeconomic segmentation and restrictions on access to the oligarchic state apparatus. It was socially more segmented in the regions where the indigenous and African population played an important role in the functioning of the export economies. It was politically more exclusive where the elites needed a more direct control of the state apparatus to guarantee economic profitability and social order. These differentiations occurred, often, within the countries, as in the cases of Mexico (between the centre, north and south), Brazil (between the northeast and the south), or Argentina (between the northwest and the Pampas region).

From the point of view of political tensions, these were very limited polyarchies. The political regimes were formally open to electoral competition, organized by constitutions guaranteeing checks and balances, and counted for the most part with universal male suffrage. Governments and public bureaucracies, however, were colonized by small elites; the elections were organized in such a way as to limit uncertainty as much as possible; and the balance of powers was a facade for inter-factional pacts. Patronage and corruption inherited from the colonial institutions were continued in co-optation mechanisms that, in a limited way, contributed to legitimize the political system. But the republics were essentially plutocratic affairs.

From the point of view of social tensions, the offers of equality continued to be essentially restricted, configuring strongly asymmetric models of material citizenship. The republics had individualist and egalitarian liberal laws. But traditionalist gender and ethnic relations, and economic opportunities monopolized by minority groups, coexisted with popular sectors very precariously linked to the monetary economy, both rural and urban, and often subject to actual servitude and slavery. Economic and social fragmentation will be one of the most resilient aspects of Latin American inequality, up to the very present.

\section{Inclusive Citizenships}

In spite of the serious conflicts that it entailed, sometimes gradually and sometimes by means of violent ruptures, as the XX century went by, Latin American states became vehicles for extending citizenship. The political systems were opened to a growing number of actors; and the republican institutions of its polyarchies tended (with ups and downs) to prevail. The universalist element of their rights systems, on the other hand, began to erode (sometimes in a fleeting and temporary way, sometimes more decisively) the inheritance of social segmentation. Finally, with controversial success, more complex capitalist productive fabric appeared, while a new generation of social policies attacked material inequalities for the first time.

Once again, political and economic crises in global centres facilitated the rupture of the national equilibriums between local elites, as well as between dominant and subaltern groups, on which exclusive citizenship regimes were based. The First World War (1914-1918), the Financial Crisis of the 1930s and the Second World War (1939-1945) altered, one after another and each in its own way, the political and economic factors on which these equilibriums had rested. The "conservative orders" 
of Latin America lost stability and legitimacy in most of the region, opening processes of socio-political transformation of considerable depth.

The most frequent mode of political manifestation of these changes was the appearance of diffusely popular nationalisms that disputed the control of the state to use it as the broker of a less unequal social pact. "Popular governments" used state resources to force the expansion of material citizenship, distributing income, infrastructure or social protection. Amalgamated by general notions of political and social justice, these new arrangements were characterized by the social sciences of the time, sometimes descriptively and others pejoratively, as populisms (TOURAINE, 1988; LACLAU, 2005). It was often about coalitions that were built around a critical reading of the inadequacies of Latin American capitalisms and the classical tools of economic development, which contributed to many of these episodes the neologism, key to Latin American history, of "developmentalism" (PREBISCH, 2008; CARDOSO and FALETTO, 1977; SUNKEL and PAZ, 2004). For the first time, regional organizations, such as ECLAC, FLACSO or CLACSO, provided areas for comparative regional discussion of strategies for addressing common problems (BIELSCHOWSKY, 1998; FRANCO, 2007).

The episodes of democratic opening and inclusive developmentalism, however, faced formidable obstacles and generated only unstable, stop-and-go processes of citizenship expansion. The conditions of consensus building for this expansion were elusive, and powerful coalitions of conflicting interests often blocked transformations. The difficulty in consolidating longterm policies aggravated tensions in processes that demanded important redistributions of political, economic and social power. A new type of low intensity war that characterized the four decades from 1950 to 1990 -the Cold War- meant, for Latin Americans, to undertake development and democratization within the narrow limits that the governing coalitions in the hegemonic state of the region, the US, considered compatible with their strategic preferences and their notions of national security (LIVINGSTONE, 2009).

Populist and developmentalist nationalisms, nevertheless, may be characterized as moments in which the tensions of citizenship opened game to more political and social inclusion. Even in spite of strong polarizations, as well as violent reactionary forces, most of them actively backed by the United States government, Latin America succeeded in expanding its political systems, giving them a more effectively polyarchic character. The economic and social policies of these expanded states, equipped with greater resources and with new instruments of state capacity, faced the segmentation, both material and symbolic, that had characterized Latin American societies since the colonial era. Successfully? Some significant markers can be brought to mind: physical integration of the territory; increase in the population able to participate in the political system as electors or elected (including in many cases female and illiterate vote); improvement of material life conditions (literacy, reduction of morbility and mortality); open incorporation of elements of multiculturalism (languages, religions) in official narratives.

There are many nuances to this generalization; all of which deserve a long discussion, unfeasible in an article. I would just like to propose a very general characterization, based on specific national features, waiting for a more detailed work, hopefully forthcoming.

Inclusive openings occurred early in Uruguay and Mexico, in the first as a modernizing correlate of urban political hegemony (1903-1916); and in the second as a result of the Revolution (1910-1920) and its most decisive legacies (1930s-1960s). Both cases could be taken as "models" for processes of inclusive openings, one gradualist and the other explosive. In both cases, there were long-term transformations that tended to lose strength and intensity with time (Mexico), or were truncated as a consequence of deepening political and social conflicts (Uruguay).

In few places of Latin America there were revolutions combining political inclusion, material modernization and symbolic de-segmentation, capable of achieving a long-term projection, such as the Mexican Revolution. Perhaps the most comparable process has been that of Bolivia, since 1943, but more decidedly between 1952 and sometime in the 1960s, where nationalist and socially transversal civic-military coalitions tried to relaunch the construction of the State and the economy national in inclusive senses.

And then there is Cuba, where the blockades to the liberal-democratic openings of the 1930s were followed by a nationalist revolution (1959) that was oriented towards socialism in the 1960s. The socialist republic radically transformed the social structure, building a citizenship that, from the classical perspective, has contradictory elements of social de-segmentation and 
political concentration of power. Regarding the popular nationalist revolutions of the region, the Cuban model was a polar political-institutional reference for, at least, two or three decades; at least until its loss of economic balance and probably of political legitimacy, as a correlate of the end of the Cold War. But, is it an intense form of citizenship? Or a paradoxical form? The author of these lines is not sure.

Perhaps at the other extreme of the reference poles one could find the liberal-democratic, moderately inclusive opening of Costa Rica. Important political and social changes that took place gradually since 1936, but more decidedly since the 40 s, produced expanding citizenship. Venezuela seemed to follow a path similar to that of Costa Rica, after 1945, with the political refoundation of a stable polyarchy and a state with resources visibly beyond its needs. Over time, however, the country's democratic political regime lost legitimacy and faced spiralling political and social protest.

Most of the openings in the region were politically unstable, paradoxical or contradictory, although their social effects may have favoured the expansion and / or de-segmentation of material citizenship. In some national cases, long-term gradualist processes were truncated by the effects of the political authoritarianism of the 1970s and 1980s. It is probably the case of Brazil, which exhibits a process that can be somewhat read as a gradual extension of its citizenship (MURILO DE CARVALHO, 1995) through key conjunctures: the republicanization of the political regime on horseback of the twentieth century; the relaunching of the federal state in the 1930s; and its effective nationalization in the 1950s. The coup of 1964 and the subsequent dictatorships froze or reoriented this process in an authoritarian and exclusive sense. Similarly, although more dramatically, can be read the case of Chile. The process of opening and moderate inclusion that began in the 1920s, has a violent closure in 1973.

Many openings were less substantive than those cited (El Salvador, 1930); they were truncated faster (Guatemala, 19451954); they were more tenuous (Ecuador, 1925-1930 and 1933-1935, Colombia, 1934-1948, El Salvador, 1950-1960); or they were subsumed in political violence, losing support and/or consistency (Panama, 1968, Peru, 1968, Nicaragua, 1979). A "model" of these cycles of fleeting political inclusion, on the background of unfinished social de-segmentation, was perhaps that of Argentina, with qualifying inclusive processes in 1916-1930, 1943-1955 and 1973-1976, all socially inconclusive and slowed down by violent political closures. In some cases, finally, it is difficult to grant character of inclusive openings, in any of its political or social dimensions, to the political processes of the XX century in countries such as Honduras, Paraguay, or the Dominican Republic.

All of the inclusive episodes of the XX century were unstable from the political point of view, being truncated in the violence of internal and external confrontation; or they were insufficient from the social point of view, being reduced to aspects and superficial or partial forms of citizenship de-segmentation. By the 1970s and 1980s, with the possible exception of Costa Rica, the beginnings of citizen inclusion or citizenship expansion had been doomed by processes of bureaucratization and political eliticization, as in Mexico or Venezuela; or in the authoritarianism of civic-military coalitions that used strategies of state terrorism as a tool of political exclusion or selective political inclusion, as in the Southern Cone (see ROUQUIÉ, 1984; O'DONNELL, 1996; or ANSALDI and GIORDANO, 2012b).

\section{"Inclusionist" Citizenships}

The present of Latin America is, in the sense of the periodization proposed here, a recharged continuation of the inclusive phase of citizenship. "Inclusion", a politically strong word in the region, became an explicit goal of governance. We have suggested to call this "inclusionism" (ANDRENACCI, 2012). One way of approaching the phase is to place its origins in the era of democratic transitions (O'DONNELL, SCHMITTER and WHITEHEAD, 1986), through which most of the region reencountered its republican institutions. In some cases, this implied the fall of explicitly authoritarian governments, be they military dictatorships or civil governments of state parties. In other cases, it involved processes of change in façade democracies, which in practice hid a plutocratic or oligarchic control of political arrangements (CAVAROZZI, 1991). When these new regimes were consolidated, they initiated a process of legal, economic and social reforms that, in most of the countries, implied a more determined expansion of citizenship than in the past.

Many of the causes of this "long present" were, once again, exogenous. Two key changes determined an environmental change in the operating conditions for the states of the region. Local economies, along with the rest of the world's, underwent crises 
and transformations of development models since the end of the 1970s (THORP, 1998). And the contexts of global politics dramatically changed with the end of the Cold War in the late 1980s and the consequent change in US priorities for Latin American policy (DOMÍNGUEZ, 1998).

The end of the Cold War unexpectedly opened the way to a depolarization and a substantial reduction of violence in political relations. The regional hegemon relaxed its direct control of national political situations, abandoned its systematic blockade, direct or indirect, to progressive political experiences, and withdrew support from authoritarian arrangements that had been its strategic allies. Latin American states began to channel conflicts through their own institutionality, starting a remarkable round of polyarchical consolidation.

But economic change, on the other hand, produced a paradox. Developmentalist processes had not been able to conjure the intensity of external dependence or the internal imbalances of Latin American capitalist economies. Although not in a linear manner, the crises of the 1980s implied strong sequelae of recession, unemployment and multiplication of poverty in most countries of the region (MARQUES-PEREIRA, 1993). Unexpectedly, this facilitated the delegitimization of dominant arrangements, many of them sustaining authoritarian rule, thus easing the way for political change.

For a time, in the late 1980s and most of the 1990s, governments that emerged from the collapse of dictatorships or the implosions of limited democratic arrangements faced economic change with authoritarian styles that limited the effective scope of democratization, and with instruments of neoclassical economic policy that exacerbated the negative social effects of the crises. The label "neoliberalism" is often used for these processes. More precisely, the political arrangements of the transition gave rise to delegative democracies that produced low intensity citizenship (O'DONNELL, 1993, 1994). Delegative democracies were polyarchies of a peculiar kind, in which participation rules were limited by the hegemonic position of an oversized and plebiscitary executive power, based on a restrictive governing coalition. Their economic and social policy options failed (with the controversial exception of Chile) to address the problems of extremely unequal and highly segmented societies and territories, to the point of making the material aspect of the economy illusory (or hypocritical) relative to the expectations brought about by democratization. The low intensity of citizenship -the scarce or segmented effective access of citizens to the state through political participation, the law, access to economic opportunities and social infrastructureaggravated the asymmetries of delegative democracy, making it difficult to sustain the citizen legitimacy of many newly re-founded or expanded republics.

But in a second stage, since the late 1990s or the beginning of the XXI century, factors re-combined in a virtuous way. More representative arrangements, and generally less limited democracies, began to address, in a more favourable economic context and with greater state autonomy, the problem of effective citizen inclusion. With some ups and downs and partial or temporary exceptions, the process became surprisingly homogenous. It even became in many ways independent of the ideological sign of governing coalitions, even if progressive nationalist governments were naturally prone to more aggressively "inclusionist" public policy choices (ARNSON, JARA and ESCOBAR, 2009).

Although the political system did not lose its delegative ways, it did become more open, stable and participatory. In the same way, the deployment of more inclusive economic and social policies that the region managed to launch in the favourable macroeconomic context of the first decade of the 21st century, allowed states to attack more decidedly the historical social segmentations of the region. Access to basic public services, social protection and monetary resources through the growth of employment and public spending contributed to a significant reduction in poverty and at least a part of material inequalities. Meanwhile, legal transformations allowed to deepen these processes, attacking some of the most important bases of ethnic, gender and sexual inequalities. Latin American segmentation, socle of the idea of "exclusion", suffered important questioning, and was the object of some of the most substantial empirical interventions in the history of the region.

The interpretation of the reasons, scope and potential of these "neo-developmentalist" democracies (DRAIBE and RIESCO, 2007; PINTO, 2008; BRESSER PEREIRA, 2011) that we labelled "inclusionist" (ANDRENACCI, 2012) is, of course, controversial. The processes were undertaken by heterogeneous political coalitions, with varying scope and success. Economic growth remained heteronomous and vulnerable to global cycles, reducing the political and financial margins of the states. Inclusion promoted by public spending, without added complexity to productive matrices, or effective institutionalization of social rights, may be reversible. Latin American "entangled inequalities" will not be disentangled that easily (COSTA, 2011).

Moreover, towards the end of the first decade of the 21st century, a new change in global economic environments brought havoc to the underlying factors of this positive transformation, revealing some of its limitations and contradictions. The 2010s 
mercilessly brought back to the table all of the old ghosts: the fragility of economic development, the precariousness of state capacities, and thus the volatility of socioeconomic inclusion. The new crises also strained the limits of polyarchies, with at least Nicaragua, Venezuela, Honduras, Paraguay and Brazil sailing again on institutionally opaque waters. Is it a new critical juncture, capable of freezing or neutralizing the inclusive transformations of the first part of the 21st century? It is too early to answer this question.

\section{A (NECESSARILY) PROVISORY CONCLUSION}

I have argued here that this long-term view on the history of citizenship in Latin America, as a complex of sociocultural, sociopolitical and socioeconomic tensions generating points of equilibrium between critical junctures, allows us to perceive some interesting aspects of the ways in which social and political inclusion was deployed -or not- in the territorial states of the region. A less problematic and more universal inclusion, less unequal and more stable, was an elusive goal for at least half of the independent history of these countries. But in the last (long) century it was less elusive; and in the last two decades even less so.

The dynamics of a broadening citizenship, which we have proposed to redefine as inclusion, desegmentation and reduction of inequalities, are not what T. H. Marshall described for the United Kingdom, and other observers keenly generalized for Western Europe or North America. Neither is unreasonable to make comparisons. In this region it seems to have been the expansion (gradual or explosive) of political participation that opened the roads of a more egalitarian civil law and the improvement of material conditions for the majorities. Yet at the same time, as in other regions, political conflict weakens development processes and aggravates the heteronomy of state capacities, compromising the linearity of citizen expansion.

If this perspective is adequate, the keys to a positive continuity in the expansion of Latin American citizenship, like that of the last two decades, are in its political system. Specifically, in how elites and government coalitions maintain the question of citizenship at the centre of public policy agendas, legitimizing polyarchies with inclusive processes as effective as possible. 


\section{REFERENCES}

AMORIM, M. N.; BOLEDA, M. Las poblaciones ibéricas e iberoamericanas en perspectiva histórica. Buenos Aires: EUDEBA, 2009.

ANDRENACCI, L. Imparis Civitatis. Sociohistórica, n. 13-14, p. 79-108, 2003.

ANDRENACCI, L. From developmentalism to inclusionism: on the transformation of Latin American welfare regimes in the early 21st century. Journal für Entwicklungspolitik, v. 28, n. 1, p. 35-37, 2012.

ANDREWS, G. Citizenship. London: Lawrence \& Wishart, 1991.

ANNINO, A.; GUERRA, F. X. Inventando la nación. México: Fondo de Cultura Económica, 2003.

ANSALDI, W.; GIORDANO, V. América Latina: la construcción del orden (I y II). Buenos Aires: Ariel, 2012.

ARMITAGE, D.; GULDI, J. Le retour de la longue durée: une perspective anglo-américaine. Annales. Histoire, Sciences Sociales, v. 70e année, n. 2, p. 289-318, 2015.

ARNSON, C.; JARA, J. \& ESCOBAR, N. Pobreza, desigualdad y la 'Nueva Izquierda' en América Latina. Washington, DC: Woodrow Wilson International Center for Scholars, 2009. (Democratic Governance and the New Left, Report n. 6).

ARRIGHI, G. The Long Twentieth Century. London: Verso, 1999.

BEINER, R. Theorizing Citizenship. Albany: SUNY, 1995.

BENDIX, R. Nation-building and Citizenship. New Brunswick: Transaction, 1996.

BETHELL, L. Historia de América Latina. Tomo 1. Barcelona: Crítica, 1990.

BIELSCHOWSKY, R. Cincuenta años del pensamiento de la CEPAL: una reseña. Santiago de Chile: Fondo de Cultura Económica-CEPAL, 1998. (Cincuenta años de pensamiento de la CEPAL - Textos seleccionados, v. I.).

BIRNBAUM, P. Sur la citoyenneté. L'Année Sociologique, v. 46, n. 1, p. 57-85, 1996.

BOTTOMORE, T.; MARSHALL, T. H. Ciudadanía y clase social. Madrid: Alianza, 1998

BRAUDEL, F. Histoire et Sciences Sociales: La longue durée. Réseau, v. 5, n. 27, p. 7-37, 1987.

BRESSER PEREIRA, L. From old to new developmentalism in Latin America. In: OCAMPO, J.; ROS, J. (Ed.). The Oxford Handbook of Latin American Economics. Oxford University Press, 2011.

CARDOSO, F.; FALETTO, E. Dependencia y desarrollo en América Latina. Buenos Aires: Siglo XXI, 1977.

CAVAROZZI, M. Más allá de las transiciones a la democracia en América Latina. Revista de Estudios Políticos (Nueva Época), n. 74, p. 85-111, Oct./Dec.1991.

CHIARAMONTE, J. C. Nación y Estado en Iberoamérica. Buenos Aires: Sudamericana, 2004

COLLIER, R. B.; COLLIER, D. Shaping the Political Arena: Critical Junctures, the Labor Movement and Regime Dynamics in Latin America. Notre Dame: University of Notre Dame Press, 2002.
COSTA, S. Researching Entangled Inequalities in Latin America: The Role of Historical, Social, and Transregional Interdependencies. Berlin: DesiguALdades.net, 2011. (Working Paper, n. 9).

DAGNINO, E. Los significados de ciudadanía en América Latina. In: CHAPARRO, A.; GALINDO, C.; SALLENAVE, A. M. (Ed.). Estado, democracia y populismo en América Latina. Bogotá: Universidad del Rosario, 2008

DAHL, R. Polyarchy: Participation and Opposition. New Haven: Yale University Press, 1971.

DOMÍNGUEZ, J. International Security and Democracy: Latin America and the Caribbean in the Post-Cold War Era. Pittsburgh: University of Pittsburgh, 1998.

DONZELOT, J. L’invention du social. Paris: Fayard, 1984.

DRAIBE, S.: RIESCO, M. Latin America. A New Developmental Welfare State Model in the Making? New York: Palgrave-Macmillan, 2007.

EVANS, P. Embedded Autonomy. Princeton: Princeton University Press, 1995.

FLEURY, S. Estado sin ciudadanos. Buenos Aires: Lugar, 1997.

FRANCO, R. La FLACSO clásica (1957-1973): Vicisitudes de las Ciencias Sociales latinoamericanas. Santiago de Chile: Catalonia, 2007.

GIDDENS, A. The Nation-state and Violence. Cambridge: Polity Press, 1996.

GUERRA, F. X. Modernidad e independencias. México: Fondo de Cultura Económica, 2001.

HEATER, D. What is Citizenship? Cambridge: Polity Press, 1999.

LACLAU, E. La razón populista. Buenos Aires, Fondo de Cultura Económica, 2005.

LEYDET, D. Citizenship. Stanford: The Stanford Encyclopedia of Philosophy, 2017. Available at: <https://plato.stanford.edu/archives/ fall2017/entries/citizenship/> Accessed on: Oct. 31, 2018.

LIVINGSTONE, G. America's Backyard. Londres: Zed Books, 2009.

LYNCH, J. Las revoluciones hispanoamericanas 1808-1826. Barcelona: Ariel, 2008.

MAGNETTE, P. La Citoyenneté dans la pensée politique européenne. Res Publica, v. 38, n. 3-4, p. 657-678, 1996.

MANN, M. The sources of social power. Vol. I. Cambridge: Cambridge University Press, 1997.

MANN, M. The sources of social power. Vol. III. Cambridge: Cambridge University Press, 2012.

MARQUES-PEREIRA, J. Les limites de l'Etat en Amérique Latine: citoyenneté, intervention sociale et croissance économique. Cahiers des Amériques Latines, Paris, n. 15, p. 109-134, 1993.

MURILO DE CARVALHO, J. Desenvolvimiento de la ciudadanía en Brasil. México: Fondo de Cultura Económica, 1995.

O’DONNELL, G. Acerca del Estado, la democratización y algunos problemas conceptuales. Desarrollo Económico, v. 33, n. 130, p. 163-184, 1993. 
O'DONNELL, G. Delegative Democracy. Journal of Democracy, v. 5, n. 1, p. 55-69, 1994.

O'DONNELL, G. El Estado Burocrático Autoritario: triunfos, derrotas y crisis. Buenos Aires: Editorial de Belgrano, 1996.

O'DONNELL, G. Polyarchies and the (un)rule of law in Latin America. Indiana: Helen Kellogg Institute, 1998. (Working Paper, n. 254).

O'DONNELL, G. Democracia, agencia y estado. Buenos Aires: Prometeo, 2010.

O'DONNELL, G.; SCHMITTER, P.; WHITEHEAD, L. Transitions from Authoritarian Rule. Johns Hopkins University Press, 1986.

PEASE, F.; MOYA PONS, F. Historia General de América Latina, Volumen II. Paris: UNESCO-Trotta, 2000.

PINSKY, J.; BASSANEZI PINSKY, C. História da Cidadania. São Paulo: Contexto, 2005

PINTO, A. Notas sobre los estilos de desarrollo en América Latina. Revista de la CEPAL, n. 96, p. 73-93, dec. 2008.

PREBISCH, R. Hacia una teoría de la transformación. Revista de la CEPAL, n. 96, p. 27-71, dec. 2008.

RIESENBERG, P. Citizenship in the Western Tradition. Chapel Hill: University of North Carolina Press, 1992.

ROCHE, M. Rethinking Citizenship. Londres: Polity Press, 1992.

ROJAS RABIELA, T.; MURRA, J. Historia General de América Latina, Volumen I. Paris: UNESCO-Trotta, 1999.

ROSANVALLON, P. Le sacre du citoyen. Paris: Gallimard, 1992.

ROSANVALLON, P. Le bon gouvernement. Paris: Seuil, 2015.

ROUQUIÉ, A. El Estado militar en América Latina. Buenos Aires: Emecé, 1984.
SÁBATO, H. Ciudadanía política y formación de las naciones. México, DF: El Colegio-Fondo de Cultura Económica, 1999.

SKINNER, Q. The Foundations of Modern Political Thought, Volume 1. Cambridge: Cambridge University Press, 2010.

SOMERS, M. Genealogies of Citizenship. Cambridge: Cambridge University Press, 2008.

SUNKEL, O.; PAZ, P. El subdesarrollo latinoamericano y la teoría del desarrollo. México, DF: Siglo XXI, 2004.

TELLES, E.; PERLA Pigmentocracies: ethnicity, race, and color in Latin America. Chapel Hill: University of North Carolina, 2014.

THOM, M. Republics, Nations and Tribes. Londres: Verso, 1995.

THORP, R. Progress, Poverty and Exclusion. Washington, DC: BIDJohns Hopkins, 1998.

TILLY, C. The Emergence of Citizenship in France and Elsewhere. International Review of Social History, v. 40, n. S3, p. 223-236, 1995.

TILLY, C. Durable Inequality. Berkeley: University of California, 1999.

TILLY, C. Identities, Boundaries \& Social Ties. Londres: Paradigm, 2005.

TOURAINE, A. La parole et le sang. Paris: Odile Jacob, 1998.

TURNER, B. Citizenship and Social Theory. Londres: Sage, 1993.

WALZER, M. Spheres of Justice. New York: Basic Books, 1983.

WEAVER, K.; ROCKMAN, B. Do Institutions Matter? Washington, DC: Brookings, 1993.

YOUNG, I. Vida política y diferencia de grupo: una crítica del ideal de ciudadanía universal. In: CASTELLS, C. Perspectivas feministas en teoría política. Barcelona: Paidós, 1996.

ZOLO, D. La cittadinanza: appartenanza, identità, diritti. Roma: Laterza, 1994. 